\title{
Implementation of Green New Product Development Among SMEs: Barriers and Critical Success Factors
}

\author{
Noor Hidayah $\mathrm{Abu}^{1 *}$ Khoo Kean Huat ${ }^{1}$, and M. F. Mansor ${ }^{3}$ \\ 1, School of Technology Management and Logistics, University Utara Malaysia, Sintok, 06010 Universiti Utara Malaysia, Kedah \\ ${ }^{3}$ School of Business Innovation \& Technopreneurship, Universiti Malaysia Perlis, 01000 Kangar Perlis, Malaysia.
}

\begin{abstract}
Green New Product Development (GNPD) is very important due to environmental issues increasing. GNPD is defined as creating, designing and develop ecological product which could help in protecting the environment. Small and medium enterprise (SME) firms is one of the contributor to the environmental issues but they could not afford to implement GNPD because there are several obstacles which prevent the successful of GNPD implementation. The objective of this paper are to identify the critical success factors and to determine the obstacles of GNPD implementation among SMEs. The method used in this study is conceptual review of previous literature in green and NPD area of research. The result finding of this paper consist of 9 critical success factors and 12 obstacles. All the critical success factors and obstacles will be grouped. The finding of this study could be a source and fundamental guideline for future study in developing framework for GNPD implementation especially for manufacturing SMEs in Malaysia. Besides that, the result of this study could help organization especially SMEs's owner and manager in assessing their initiative to implement GNPD in organization. Key words: Small and Medium Enterprise, Green New Product Development, Environment, Eco-design, Critical Success Factors
\end{abstract}

\section{Introduction}

Today the environmental issues are increasingly integrated into international trade and market. Consumers worldwide are becoming concern for environmentally friendly products. One way to achieve and produce environmentally friendly products is through implementing Green New Product Development (GNPD) in organization. GNPD is a principle that was proposed in 1987 which is designing, developing, and producing "ecological" products by manufacture [1]. Effective implementation of Green New Product Development (GNPD) in organization will improve organization competitiveness, reducing operation cost, conserving environment, reduced energy and water consumption. In addition ecological product is an important key to reduce the negative impact on the environment as well as contribute to the improvement of product sustainability [2].

SMEs are considered as the fundamental to the development and growth of many countries. In Malaysia, SMEs from manufacturing sectors play a significant role in economic development [2]. Majority of businesses unit in Malaysia are consists of SMEs [3]. International Energy Agency stated that total emission produced by SMEs are expected to increase from $74 \%$ to $91 \%$ from year 2007 to year 2050 .
Increasing customer awareness on ecofriendly product has led to a need for all manufacturers especially SMEs to implement GNPD. However, achieving successful implementation of GNPD is not easy for most SMEs especially for those who want to transform from conventional approach to green manufacturing approach. The process of GNPD implementation is involving numerous challenge and issues. Firstly, the creation, design and function of the activities must attract, satisfy and retain customer [4]. Secondly, [5] pointed out that GNPD and sustainability practises involve a huge cost for a company to implement although it will bring a lot of benefits. Thirdly, the process of GNPD is highly complex and it requires certain high skills and knowledge to implement [5]. Besides, there are many SMEs which still confuse about "what is a GNPD?" or "what is consider as a sustainable product" [4].

SMEs requires a systematic guideline in order to implement GNPD. However most of previous studies on GNPD were concentrated more on large organization $[6,7,8,9]$ rather than SMEs. Theoretically, implementation of GNPD in SMEs must not adopt the "little big business" approach where GNPD in SMEs is viewed as a linear scalar of GNDP implementation within large organization. Hence, there is a need to fundamentally understand the process of GNPD 
implementation among SMEs, rather than fitting large organizational understanding [10].

This study is act as a beginning stage to assist SMEs in Malaysia to implement GNPD. Before executing GNPD, there are several critical factors and obstacles need to be identified. Therefore, the objective of this paper is to identify the critical success factors and to determine the obstacles of GNPD implementation among SMEs.

\section{Literature Review}

\subsection{Concept and definition of NDP}

Green NPD is evolved from NPD concept. The concept of NPD was introduced and popularized in the 1950s when manufacturers minimized the production costs through mass production [1]. As competition intensified in the 1990s, the increased awareness of green practices has triggered firms to act in an ethically and socially responsible manner in green NPD. New Product Development is the term described the complete process of new product or services that will launch in the market [11].

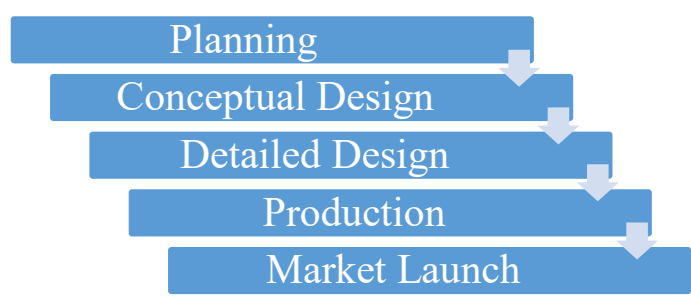

Figure 1.1: Process of New Product Development

Source: [1]

New product development stage is divided into 5 stages as shown in Figure1.1, which are planning, conceptual design, detailed design, production and market launch. Second stage and third stage is very important and must implemented properly in order to improve the product characteristics and the environmental issues [1].

\subsection{Concept and definition of GNDP}

The concept of GNPD is to minimize or eliminate wastages including hazardous chemical, emissions, energy and solid waste along designing, developing and producing product. The purpose of this concept is to improve the process and product performance in manufacturing industry based on requisite in environmental regulations. GNPD is an innovative and competitive tool for organizational sustainability to reduce environmental risk and to achieve both financial and environmental benefit simultaneously. GNPD is a general term which emphasizes a range of issues from the existing product, redesign the product and creating a new product based on green and eco-design concept [12]. GNPD is clarify as the development of new product which consider the environmental as a very importance issues and explicitly integrated in order to create as least product of environmental harmful as industries can [4].

\subsection{Malaysian Manufacturing SMEs}

An organization or manufacturing are classified as SMEs when they employed fulltime employees between 5-150 peoples or achieving annual sales less than RM25 millions [3]. According to Malaysian Statistical Department census 2014, there are total number of 645,136 SMEs in Malaysia. Table 1.1 shows the number of SMEs by sector in Malaysia.

Table 1.1 Types of SMEs in Malaysia Source: [3]

\begin{tabular}{|l|c|c|c|c|}
\hline Sector & $\begin{array}{l}\text { Total } \\
\text { Establish } \\
\text { ments }\end{array}$ & $\begin{array}{l}\text { Total } \\
\text { SMEs }\end{array}$ & $\begin{array}{l}\text { Percentage of } \\
\text { SMEs over } \\
\text { total establish } \\
* 100\end{array}$ & $\begin{array}{l}\text { Total } \\
\text { Employment } \\
\text { by SMEs }\end{array}$ \\
\hline $\begin{array}{l}\text { Overall } \\
\text { Total }\end{array}$ & 662,939 & 645,136 & 97.3 & $3,669,259$ \\
\hline Services & 591,883 & 580,985 & 98.1 & $2,610,373$ \\
\hline $\begin{array}{l}\text { Manufactur } \\
\text { ing }\end{array}$ & 39,669 & 37,861 & 95.4 & 698,713 \\
\hline Agriculture & 8,829 & 6,708 & 76.0 & 78,777 \\
\hline $\begin{array}{l}\text { Constructio } \\
\mathrm{n}\end{array}$ & 22,140 & 19,283 & 87.1 & 275,631 \\
\hline $\begin{array}{l}\text { Mining \& } \\
\text { Quarrying }\end{array}$ & 418 & 299 & 71.5 & 5,765 \\
\hline
\end{tabular}

Within these 6 sectors of SMEs in Malaysia, each sectors will at least contributed to some extent of pollution and generate environmental issues. According to [1] the percentage of environment issues that contributed by SMEs is over $80 \%$ in waste. Table 1.2 shows the percentage of firm's activities which impact on the environment by considering 148 SMEs as respondent. 
Table 1.2 percentage of SME's activities which impact on the environment

\begin{tabular}{|l|c|c|}
\hline Firm's activities & $\begin{array}{c}\text { No. of } \\
\text { Firm }\end{array}$ & $\begin{array}{c}\text { Percentage of } \\
\text { Firm (\%) }\end{array}$ \\
\hline Processes & 51 & 34.5 \\
\hline Waste & 127 & 85.8 \\
\hline Emissions & 40 & 27.0 \\
\hline $\begin{array}{l}\text { Purchasing } \\
\text { Policies }\end{array}$ & 34 & 23.0 \\
\hline Transport & 74 & 50.0 \\
\hline $\begin{array}{l}\text { Visual/Noise } \\
\text { disturbance }\end{array}$ & 20 & 13.5 \\
\hline Others & 8 & 5.4 \\
\hline None of the above & 9 & 6.1 \\
\hline
\end{tabular}

\section{Research Methodology}

The research method used is conceptual based. Secondary sources were identified from literatures obtained from research journals, reports, articles, books, newspapers as well as empirical analysis on SMEs manufacturing. Most data is from journal or article written and published between years 2005 until 2016. Those article are searched and collected by using the search strings "Green Management", "Green Innovation", "Green Supply Chain Management", "Eco-Design Products", "Sustainable Practises", "Green New Product Development", "SMEs Practises in Green Management" and "Environment issues by SMEs". This paper will collecting, summarizing and analysing data collected from article resources. These analysed factors from most importance to least importance can provide SMEs a guideline to evaluate their performance when implementing GNPD.

\section{Finding of paper}

The finding have shown that there are nine Critical Success Factors (CSFs) that able to support effective implementation GNPD in SMEs. The CSFs are: commitment of leader, efficiency in energy and resources consumption, effective in product innovation, good relationship with supplier, strategic location, effective communication, established an environmental risk management system, skills \& experience manpower, and sufficient manpower. The nine CSFs can be grouped into 7 core values categories, which shown in table 1.3
Table 1.3 Critical Success Factors for GNPD Implementation

\begin{tabular}{|c|c|c|}
\hline & $\begin{array}{l}\text { Critical Success } \\
\text { Factors }\end{array}$ & $\begin{array}{l}\text { Relevant } \\
\text { Literature }\end{array}$ \\
\hline $\begin{array}{l}\text { Organization } \\
\text { Resources } \\
\text { Management }\end{array}$ & $\begin{array}{l}\text { Efficiency in } \\
\text { Energy and } \\
\text { Resources } \\
\text { Consumption }\end{array}$ & $\begin{array}{l}\text { [13] Tochukwu et } \\
\text { al (2016), } \\
\text { [14] Lee, (2009), } \\
\text { [15]Papadopoulos } \\
\text { et al (2014) }\end{array}$ \\
\hline $\begin{array}{l}\text { Innovation } \\
\text { initiative }\end{array}$ & $\begin{array}{l}\text { Good in Product } \\
\text { Innovation }\end{array}$ & $\begin{array}{l}\text { [16] Stanley } \\
(2012), \\
\text { [17] Yi-Chun et } \\
\text { al (2010), } \\
\text { [18] Allen (2010) }\end{array}$ \\
\hline $\begin{array}{l}\text { Mentoring } \\
\text { Management }\end{array}$ & $\begin{array}{l}\text { Commitment of } \\
\text { leader }\end{array}$ & $\begin{array}{l}\text { [19] Sang et al., } \\
\text { (2012), } \\
\text { [13] Tochukwu et } \\
\text { al., (2016) }\end{array}$ \\
\hline \multirow[t]{2}{*}{$\begin{array}{l}\text { Supplier } \\
\text { Management }\end{array}$} & $\begin{array}{l}\text { Good } \\
\text { Relationship with } \\
\text { Supplier }\end{array}$ & $\begin{array}{l}\text { [19] Sang M. et al } \\
(2012), \\
\text { [18] Allen et al } \\
(2010), \\
\text { [20] Lee, (2008) }\end{array}$ \\
\hline & $\begin{array}{l}\text { Strategic } \\
\text { Location }\end{array}$ & $\begin{array}{l}\text { [13] Tochukwu et } \\
\text { al (2016) }\end{array}$ \\
\hline $\begin{array}{l}\text { Risk } \\
\text { Management }\end{array}$ & $\begin{array}{l}\text { Established an } \\
\text { Environmental } \\
\text { Risk } \\
\text { Management } \\
\text { System }\end{array}$ & $\begin{array}{l}\text { [15]Papadopoulos } \\
\text { et al (2014), } \\
\text { [18] Allen et al } \\
\text { (2010) }\end{array}$ \\
\hline \multirow[t]{3}{*}{$\begin{array}{l}\text { Labour } \\
\text { management }\end{array}$} & $\begin{array}{l}\text { Sufficiency of } \\
\text { manpower }\end{array}$ & $\begin{array}{l}\text { [14] Lee, }(2009), \\
\text { [18] Allen et al } \\
(2010)\end{array}$ \\
\hline & $\begin{array}{l}\text { Require Skills } \\
\text { and Work } \\
\text { Experience }\end{array}$ & $\begin{array}{l}\text { [14] Lee, (2009), } \\
\text { [15]Papadopoulos } \\
\text { et al (2014), } \\
\text { [13] Tochukwu et } \\
\text { al (2016) }\end{array}$ \\
\hline & $\begin{array}{l}\text { Effective } \\
\text { Communication }\end{array}$ & $\begin{array}{l}\text { [15]Papadopoulos } \\
\text { et al (2014), } \\
\text { [13] Tochukwu et } \\
\text { al (2016) }\end{array}$ \\
\hline
\end{tabular}

From the literature, there are at list twelve obstacles that have been identified for GNPD implementation in SMEs. The barriers are: cost implication, financial constraint, negative perspective on sustainability, culture diversity, constraint of resources, resistance to adopt new technology, lack of technical expertise, lack of manpower, market competition and uncertainty, fear of failure, lack of top management commitment, and lack of customer awareness toward GNPD. Same as CSFs, these factors will be grouped into seven core values categories. Table 1.4 shows the obstacles of GNPD implementation. 
Table 1.4 Obstacles of GNPD implementation

\begin{tabular}{|c|c|c|}
\hline & Obstacles & $\begin{array}{l}\text { Relevant } \\
\text { Literature }\end{array}$ \\
\hline \multirow[t]{2}{*}{$\begin{array}{l}\text { Financial } \\
\text { problem }\end{array}$} & Cost implications & $\begin{array}{l}{[21] \text { Sreejith }} \\
(2012), \\
{[22] \text { Hosseini }} \\
(2007), \\
\text { Stanley (2012) }\end{array}$ \\
\hline & $\begin{array}{l}\text { Financial } \\
\text { constraint }\end{array}$ & $\begin{array}{l}\text { [15] Ioannis et } \\
\text { al., (2014) }\end{array}$ \\
\hline \multirow[t]{4}{*}{$\begin{array}{l}\text { Organization } \\
\text { culture }\end{array}$} & $\begin{array}{l}\text { Negative } \\
\text { perspective } \\
\text { sustainability }\end{array}$ & $\begin{array}{l}\text { [23]Setthasakk } \\
\text { o, (2009) }\end{array}$ \\
\hline & Culture Diversity & $\begin{array}{l}\text { [23]Setthasakk } \\
\text { o, (2009) }\end{array}$ \\
\hline & $\begin{array}{l}\text { Resistance to adopt } \\
\text { new technology }\end{array}$ & $\begin{array}{l}\text { [24] Wu and } \\
\text { Hang (2009), }\end{array}$ \\
\hline & Fear of Failure & $\begin{array}{l}{[25] \text { Rao and }} \\
\text { Holt }(2005),\end{array}$ \\
\hline $\begin{array}{l}\text { Resources } \\
\text { Problem }\end{array}$ & $\begin{array}{l}\text { Constraints of } \\
\text { resources }\end{array}$ & $\begin{array}{l}16] \text { Stanley } \\
(2012), \\
\text { [26] Jiju et al } \\
(2005) \text {, }\end{array}$ \\
\hline \multirow[t]{2}{*}{$\begin{array}{l}\text { Lack of expert } \\
\text { and skills } \\
\text { worker }\end{array}$} & $\begin{array}{l}\text { Lack of technical } \\
\text { expertise to } \\
\text { implement GNPD }\end{array}$ & $\begin{array}{l}\text { [27] Sharma et } \\
\text { al. (2012), } \\
{[14] \quad \text { Lee }} \\
(2009),\end{array}$ \\
\hline & Lack of Manpower & $\begin{array}{ll}{[14]} & \text { Lee, } \\
(2009) & \\
\end{array}$ \\
\hline Competition & $\begin{array}{l}\text { Market } \\
\text { competition and } \\
\text { uncertainty }\end{array}$ & $\begin{array}{l}\text { [28] Mudgal et } \\
\text { al. (2010), } \\
\text { [22] Hosseini } \\
(2007)\end{array}$ \\
\hline $\begin{array}{l}\text { Mentoring } \\
\text { Problem }\end{array}$ & $\begin{array}{ll}\text { Lack of Top } \\
\text { Management } & \\
\text { Commitment } & \end{array}$ & $\begin{array}{l}\text { [23]Setthasakk } \\
\text { o (2009), } \\
\text { [27] Singh et } \\
\text { al. (2012), }\end{array}$ \\
\hline \multirow[t]{2}{*}{$\begin{array}{l}\text { Support from } \\
\text { external } \\
\text { organization }\end{array}$} & $\begin{array}{l}\text { Lack } \\
\text { government } \\
\text { support to adopt } \\
\text { GNPD }\end{array}$ & $\begin{array}{l}\text { [29] Daine et } \\
\text { al., (2009) }\end{array}$ \\
\hline & $\begin{array}{l}\text { Lack of customer } \\
\text { awareness toward } \\
\text { GNPD }\end{array}$ & $\begin{array}{l}\text { [21] Sreejith } \\
\text { (2012), } \\
\text { [28] Mudgal et } \\
\text { al. (2009), }\end{array}$ \\
\hline
\end{tabular}

\section{Conclusion and Discussion}

From the critical review of previous literature, it can be conclude that there are nine Critical Success Factors under seven core values of GNPD implementation had been identified. In addition twelve obstacles had been identified from rigorous review of some article in GNPD. The finding could be a source and fundamental guideline for future research to develop GNPD implementation framework for manufacturing SMEs as illustrate in the figure 1.3 below:

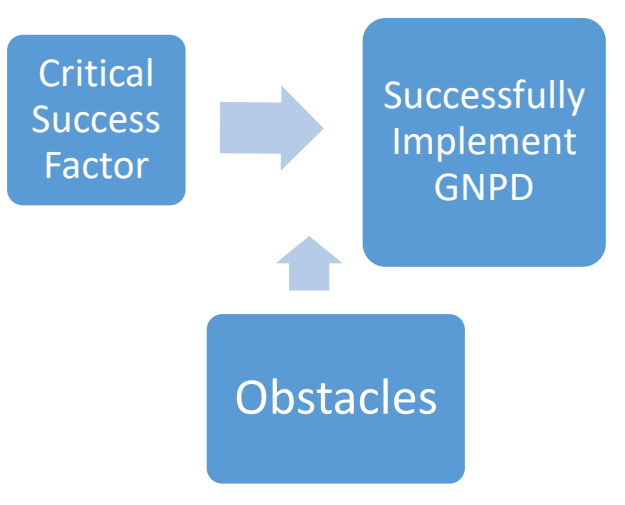

Figure 1.3: Proposal of GNPD implementation framework for manufacturing SMEs

For the future phase, the factors that has been identified in this study such as CSFs, obstacles and successful GNPD implementation will be validate via questionnaire. A set of questionnaire will construct and developed based from the finding. The questionnaire will be distribute among manufacturing SMEs in Malaysia. All Malaysian manufacturing SMEs that are certified in MS ISO 14001 will choose and involve in future study. Based on Standards and Industrial Research Institute of Malaysia (SIRIM) and Federation of Malaysian Manufacturers (FMM) directory in August 2014, there were 722 ISO 14001 certified manufacturing companies in Malaysia.

Environmental issues is critical nowadays and everyone have responsibilities to protect it especially SME industry. The purpose of this paper was to review current CSF and obstacle for GNPD implementation. The finding can be guideline for SMEs in their initiative on GNPD implementation activities. SMEs play a major role in the economic growth and provide most of new job for Malaysian. However at the same time SMEs pose serious environmental problems due to their high number and cumulative effect. It is important for SME to implement GNPD in order to protect the environment. Although Implementation of GNPD is importance for SMEs, SMEs cannot afford to make sure GNPD can be successful because there are several limitation of SME that prevent GNPD from Successful such as lack of knowledge, expertise, skills, finance and human resources. The finding of this paper have shown several critical success factors and obstacles for GNPD implementation. This finding can provide SMEs Malaysia a guideline to evaluate the performance of GNPD implementation. 


\section{Reference}

1. Pochat S. L., Gwenola Bertoluci, Daniel Froelich - Integrating ecodesign by conducting changes in SMEs - Journal of Cleaner Production - Vol. 15, p.671-680-2006

2. Paul Knight/James O. Jenkins (2006). Adopting and Applying Eco-Design Techniques: A Practitioners erspective. Research and Development Department.

3. SME Corporation Malaysia

Online:smecorp.gov.my

4. Dangelico R. M., Devashish Pujari (2010). Mainstreaming Green Product Innovation: Why and How Companies Integrate Environmental Sustainability. Journal of Business Ethics, 471-486.

5. Hart, S. (2007), "Beyond greening: strategies for a sustainable world", in Harvard Business Review on Green Business Strategy, Harvard Business School Publishing Corporation, Boston, MA.

6. Keith Goffin Colin New, (2001),"Customer support and new product development - An exploratory study", International Journal of Operations \& Production Management, Vol. 21 Iss 3 pp. $275-301$

7. Woodcock D.J. Mosey S.P. Wood,T.B.W. (2000),"New product development in British SMEs", European Journal of Innovation Management, Vol. 3 Iss 4 pp. 212 - 222

8. Bjarne JensenHanne Harmsen, (2001),"Implementation of success factors in new product development ?", European Journal of Innovation Management, Vol. 4 Iss 1 pp. 37 52

9. Naga Vamsi Krishna Jasti Aditya Sharma Shashikantha Karinka , (2015),"Development of a framework for green product development", Benchmarking: An International Journal, Vol. 22 Iss 3 pp. $426-445$

10. Rodney McAdam, Frances Fulton, (2002) "The impact of the ISO 9000:2000 quality standards in small software firms", Managing Service Quality: An International Journal, Vol. 12 Iss: 5, pp.336 - 345 .

11. Trevor Cadden Stephen John Downes, (2013),"Developing a business process for product development", Business Process Management Journal, Vol. 19 Iss 4 pp. 715 - 736

12. Berchicci, L. and Bodewes, W. (2005), "Bridging environmental issues with new product development", Business Strategy and the Environment, Vol. 14 No. 5, pp. 272-285.

14. Ki-Hoon Lee, (2009),"Why and how to adopt green management into business organizations?" Management Decision, Vol. 47 Iss 7 pp. 1101 1121
15. Ioannis Papadopoulos, Glykeria Karagouni , Marios Trigkas , Zoi Beltsiou , (2014) "Mainstreaming green product strategies: Why and how furniture companies integrate environmental sustainability?", EuroMed Journal of Business, Vol. 9 Iss: 3, pp.293 - 317

16. Stanley Kam-Sing Wong, (2012),"The influence of green product competitiveness on the success of green product innovation", European Journal of Innovation Management, Vol. 15 Iss 4 pp. 468 $-490$

18. Allen H. Hu Chia-Wei Hsu, (2010),"Critical factors for implementing green supply chain management practice", Management Research Review, Vol. 33 Iss 6 pp. 586-608

19. Sang M. Lee Sung Tae Kim Donghyun Choi, (2012),"Green supply chain managementand organizational performance", Industrial Management \& Data Systems, Vol. 112 Iss 8 pp. $1148-1180$

20. Su-Yol Lee, (2008),"Drivers for the participation of small and medium-sized suppliers in green supply chain initiatives", Supply Chain Management: An International Journal, Vol. 13 Iss 3 pp. $185-198$

21. Sreejith, B. (2012), “A hierarchical framework of barriers to green supply chain management in the construction sector", Journal of Sustainable Development, Vol. 10, pp. 15-27.

22. Hosseini, A. (2007), "Identification of green management of system's factors - a conceptualized model", International Journal of Management Science and Engineering Management, Vol. 2 No. 3, pp. 221-228.

23. Watchaneeporn Setthasakko, (2009),"Barriers to implementing corporate environmental responsibility in Thailand", International

25. Rao, P. and Holt, D. (2005), "Do green supply chains lead to competitiveness and economic performance", International Journal of Operations \& Production Management, Vol. 5 No. 25, pp. 898-916.

26. Jiju Antony, Maneesh Kumar, Christian N. Madu, (2005) "Six sigma in small- and mediumsized UK manufacturing enterprises: Some empirical observations", International Journal of Quality \& Reliability Management, Vol. 22 Iss: 8, pp.860 - 874

27. Sharma, B.P., Singh, M.D. and Neha (2012), "Modeling the knowledge sharing barriers using an ISM approach", International Conference on Information and Knowledge Management, Vol. 45, pp. 233-238.

28. Daine, H. (2009), "An analysis of the drivers affecting the implementation of green supply chain management", Journal of Resources, Conservation and Recycling, Vol. 55 No. 6, pp. 659-667. 
29. Mudgal, R.K., Shankar, R., Talib, P. and Raj, T. (2010), "Modeling the barriers of green supply chain practices: an Indian perspective",
International Journal of Logistics Systems and Management, Vol. 7 No. 1, pp. 81-107. 